\title{
Effects of dorzolamide/timolol and tafluprost on intraocular pressure and pupil diameter in healthy dogs
}

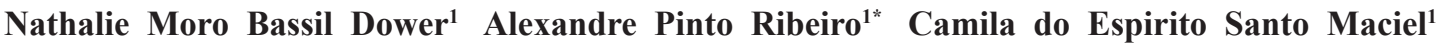 \\ Paulo Roberto Spiller ${ }^{1}$ Geovanna Barreira Monteiro' ${ }^{1}$ Fábio Dumit Pizzinatto ${ }^{1}$ \\ Kelly Cristiane Ito Yamauchi ${ }^{2}$
}

\footnotetext{
'Faculdade de Medicina Veterinária, Universidade Federal de Mato Grosso (UFMT), Av. Fernando Correa da Costa, 2367, Boa Esperança, 78015-160, Cuiabá, MT, Brasil. E-mail: alexandre.aleribs@gmail.com. "Corresponding author.

${ }^{2}$ Universidade de Cuiabá (UNIC), Cuiabá, MT, Brasil.
}

\begin{abstract}
This study aimed to evaluate and compare the effects of the fixed combination of dorzolamide/timolol with those of tafluprost on intraocular pressure (IOP) and pupil diameter (PD) in healthy dogs $(n=10)$. Two experiments were conducted with an interval of 30 days. In both, IOP and PD were assessed at 8,11,14, 17, and 20h. Parameters were evaluated during baseline, treatment period of four days, and one day of post-treatment. During treatment phase, IOP decreased by $0.74(P<0.05), 1.88(P<0.01), 2.94(P<0.001)$, and 3.10mm $\mathrm{mg}(P<0.01)$, in dorzolamide/timolol-treated eyes; and by $1.50,2.18,2.14$, and $2.18 \mathrm{mmHg}(P<0.001)$, in tafluprost-treated eyes. PD decreased by 0.24 $(P<0.01), 0.32$ ( $P<0.01), 0.49$ ( $P<0.001)$, and $0.40 \mathrm{~mm}(P<0.001)$, in dorzolamide/timolol treated eyes; and by 2.31, 2.55, 2.43, and $2.70 \mathrm{~mm}$ $(P<0.001)$, in tafluprost-treated eyes. Dorzolamide/timolol and tafluprost were able to decrease IOP and PD in healthy dogs. However, a cumulative effect of the fixed combination of dorzolamide/timolol was more effective in reducing IOP, than tafluprost. Comparisons between treatments showed that tafluprost was more effective in reducing PD throughout the treatment phase.

Key words: carbonic anhydrase inhibitor, beta blocker, prostaglandin analogs, glaucoma, dogs.
\end{abstract}

Efeitos da dorzolamida/timolol e da tafluprosta sobre a pressão intraocular e o diâmetro pupilar em cães saudáveis

\begin{abstract}
RESUMO: O estudo objetivou avaliar e comparar os efeitos da combinação fixa da dorzolamida/timolol com os da tafluprosta sobre a pressão intraocular (PIO) e o diâmetro pupilar (DP) em cães saudáveis $(n=10)$. Dois experimentos com intervalo de 30 dias foram conduzidos. Em ambos, a PIO e o DP foram avaliados às $8,11,14,17$ e às 20h. Os parâmetros foram avaliados durante a fases basal, um periodo de tratamento de quatro dias, e um dia de pós-tratamento. Durante a fase de tratamento, a PIO dos olhos tratados com dorzolamida/timolol reduziram em 0.74 ( $P<0.05), 1.88$ ( $P<0.01), 2.94$ ( $P<0.001)$, e $3.10 \mathrm{mmHg}(P<0.01)$; e dos olhos tratados com tafluprosta em 1.50, $2.18,2.14$ e $2.18 \mathrm{mmHg}(P<0.001)$. O DP dos olhos tratados com dorzolamida/timolol reduziram em $0.24(P<0.01), 0.32(P<0.01), 0.49(P<0.001)$ e 0.40mm ( $P<0.001)$; e dos olhos tratados com tafluprosta em 2.31, 2.55, 2.43 e 2.70mm $(P<0.001)$. A dorzolamida/timol e a tafluprosta foram capazes de reduzir a PIO e o DP em cães saudáveis. Porém, efeito cumulativo do tratamento com dorzolamida/timolol foi observado, decorridos três dias de tratamento. Por essa razão, a dorzolamida/timolol foi mais efetiva que a tafluprosta na redução da PIO. Comparações entre os tratamentos demonstraram que a tafluprosta foi mais efetiva em reduzir o DP, durante toda a fase de tratamento.

Palavras-chave: inibidores da anidrase carbônica, beta bloqueador, análogos da prostaglandina, glaucoma, cães.
\end{abstract}

\section{INTRODUCTION}

Inadequate aqueous humor drainage increases the intraocular pressure (IOP) and may lead to glaucoma. In dogs, the primary form of this disease may result from abnormalities in the metabolism of the trabecular cells of the outflow system, as well as changes in the anatomy of the iridocorneal angle and sclerociliary cleft (PLUMMER et al., 2013; PIZZIRANI, 2015). Intraocular surgeries, systemic, immune-mediated, and neoplastic diseases may lead to the blood-aqueous barrier breakdown. Under such conditions, the influx of proteins and cells into the aqueous humor may block its physiological drainage through the trabecular meshwork of the iridocorneal angle, which may result in increased 
IOP and secondary glaucoma (PLUMMER et al., 2013; PIZZIANI, 2015). In both forms of glaucoma, the pharmacological control of IOP is required and is usually attained with drugs that directly reduce aqueous humor synthesis or drugs that increase the uveoscleral aqueous humor outflow (PLUMMER et al., 2013; SEO \& HA, 2015).

Dorzolamide is a carbonic anhydrase inhibitor (CAI) that reduces the activity of carbonic anhydrase II secreted by non-pigmented ciliary epithelial cells, which keeps bicarbonate ions from being transported along with the sodium cation to the posterior chamber of the eye. Thus, the osmotic gradient decreases and; consequently, so does the aqueous humor production and the IOP (PLUMMER et al., 2013). When dorzolamide is used as a monotherapy, the drug significantly decreases IOP in healthy and glaucomatous dogs (CAWRSE et al., 2001; GELATT \& MACKAY, 2001). However, the fixed combination of dorzolamide with timolol maleate, a nonselective beta blocker, proved to be more effective than dorzolamide alone, in reducing the IOP and pupil diameter (PD) in glaucomatous and healthy dogs (PLUMMER et al., 2006; BORGES et al., 2007).

Prostaglandin analogs (PGAs) are FPreceptor agonists that reduce IOP by increasing aqueous humor outflow via remodeling of the ciliary muscle extracellular matrix, subsequently increasing uveoscleral outflow (SMITH et al., 2010). These agents significantly reduce IOP and PD in healthy and glaucomatous dogs (PLUMMER et al., 2013).

Preservative is a component of ophthalmic preparations that provides antimicrobial activity and prevent decomposition of the active drug. Topical hypotensive agents are used continuously for the management of glaucoma. Therefore, significant local cytotoxic effects of preservatives may arise with long-term use of these drugs (FOGAGNOLO et al., 2015; KWAK et al., 2017). Tafluprost is a PGA with pharmacological properties similar to those of latanoprost and it is characterized by the absence of preservatives (FOGAGNOLO et al., 2015; KWAK et al., 2017). In mice, this agent was more effective in reducing the IOP, when compared to latanoprost (OTA et al., 2005). In healthy dogs and glaucomatous humans, tafluprost has similar hypotensive effects of latanoprost (TAKIYAMA et al., 2009; FOGAGNOLO et al., 2015; KWAK et al., 2017). However, the former drug caused less corneal structural changes when compared to latanoprost in glaucomatous humans (FOGAGNOLO et al., 2015). In addition, it has been reported that tafluprost significantly increased retinal blood flow in rabbits, which suggests that this drug may prevent optic nerve head and retinal degeneration associated to glaucoma (GIANNICO et al., 2016).

In glaucomatous humans, direct comparisons between tafluprost and the fixed combination of dorzolamide/timolol have demonstrated that the former drug is more effective in lowering the IOP and the ocular pulse amplitude (SEO \& HA, 2015). Nonetheless, similar studies have not been reported in the veterinary literature. Comparisons between both classes of drugs may be interesting, once it has to be considered that PGAs breakdown the blood-aqueous barrier, which precludes its use in dogs with glaucoma secondary to intraocular inflammation (JOHNSTONE MCLEAN et al., 2008). Therefore, it seemed to be reasonable to study and compare the effects of the fixed combination of dorzolamide/timolol with those of tafluprost on intraocular pressure and pupil diameter in healthy dogs.

\section{MATERIALS AND METHODS}

Ten dogs were enrolled in this study. Breeds selected included Shih-Tzu ( $\mathrm{n}=2)$, Poodle $(\mathrm{n}=2)$, and Yorkshires $(n=6)$, with average age and weight of 2.5 years (1 to 5 years) and $3.18 \mathrm{~kg}$ (1.8 to $6.3 \mathrm{~kg}$ ), respectively. Dogs were selected if no abnormalities were detected after a full clinical, ophthalmic, and hematological exam. Selected animals were kept in a room with 500 lux luminosity, $56.8 \%$ relative humidity, $20^{\circ} \mathrm{C}$ temperature (Medidor Multifunção ITMP-600, Instrutemp Instrumentos de Medição Ltda, Brasil), exposed to 12 hours of light/dark cycle, were fed with a dog dry pellet twice daily, and provided with water ad libitum. IOP measurements were assessed by means of applanation tonometry (Tono-Pen ${ }^{\circledR} \mathrm{XL}$; Medtronic Solan, USA) after instillation of one drop of $0.5 \%$ proxymetacaine (Anestalcon ${ }^{\circledR}$, Alcon, São Paulo, Brasil) considering values achieving less than $5 \%$ standard deviation. Horizontal PD was accessed with an electronic caliper (Lee tools ${ }^{\circledR}$, Xangay, China) in standard room-light.

In order to acclimate the dogs to the procedures and examiners, all parameters were assessed for seven consecutive days at 8, 11,14, 17, and $20 \mathrm{~h}$. Following the acclimation period of seven days, the parameters were evaluated for two consecutive days at the same time points aforementioned to establish baseline IOP and PD values. On the next day, one eye of each dog was randomly assigned and treated for four consecutive days with one drop of the fixed combination of $2 \%$ dorzalamide $/ 0.5 \%$ timolol 
$\left(\right.$ Cosopt $^{\circledR}$; Alcon, São Paulo, Brasil) or a preservativefree $0.0015 \%$ tafluprost solution (Saflutan ${ }^{\circledR}$; Merck Sharp and Dohme, Campinas, São Paulo, Brasil) at $8 \mathrm{~h} 30$ and $20 \mathrm{~h} 30 \mathrm{~min}$. The fellow eyes received one drop of sterile saline solution and were used as control. During the treatment phase and on the day after the treatment had finished, all parameters were evaluated in a blind fashion at the same preestablished time points. In order to test each eye to both of drugs, two experiments were performed with an interval of 30 days.

One-way analysis of variance for repeated measures followed by the multiple comparisons Newman-Keuls test were used to assess the main effects of treatment and time, as well as their interaction in and between the control and treated eyes. Values of IOP and PD in the control and treated eyes were compared during the baseline period. Average daily IOP and PD values of the treated and control eyes assessed on the two days of the baseline period were compared to the average daily values of the treated and control eyes assessed during each day of the treatment and post-treatment periods. The average daily IOP and PD values of the treated and control eyes were also compared among the treatment days. In all occasions, values of $\mathrm{P}<0.05$ were considered significant.

\section{RESULTS AND DISCUSSION}

Our results were similar to those described in a previous research conducted in healthy dogs, that also reported the efficaciousness of the combination of dorzolamide/timolol in reducing the IOP (BORGES et al., 2007). Notwithstanding, BORGES et al. (2007) assessed the IOP-lowering effect of the fixed combination of dorzolamide/timolol after a single instillation, for only eight hours, and only considered to compare the effect of the treated eye with the control eye. In our research, when comparisons were made with the control eyes, IOP of the dorzolamide/ timolol-treated eyes were significantly reduced only from day two of the treatment period (Table 1, Figure 1A). In addition, BORGES et al. (2007) used a different methodology to calculate the IOP values, and did not acclimate dogs to tonometry for more than one hour, which not allowed authors to compare results of treated-eyes with the baseline values. In our study, comparisons between the average daily values of dorzolamide/timolol-treated eyes with the average daily values of the baseline period, showed that IOP decreased significantly by $0.74(\mathrm{P}<0.05), 1.88$ $(\mathrm{P}<0.01), 2.94(\mathrm{P}<0.001)$, and 3.10mmHg $(\mathrm{P}<0.01)$, from the first to the fourth day of the treatment period (Table 1, Figure 1A).

It has been reported a cumulative effect of the association of dorzolamide/timolol following a period of four days of treatment in glaucomatous beagles (PLUMMER et al., 2006). In our study, the IOP-lowering effect was cumulative in the eyes that received dorzolamide/timolol during the treatment phase. This parameter decreased $1.14 \mathrm{mmHg}$ from day one to day two, and decreased even further $1.06 \mathrm{mmHg}$ from day two to day three $(\mathrm{P}<0.001)$ (Table 1, Figure 1A).

We have decided to compare the isolated effect of tafluprost on IOP, once it has been reported that the combination of latanoprost with timolol, appeared

Table 1 - Average daily values of mean \pm standard error of intraocular pressure ( $\mathrm{mmHg}$ ) and pupil diameter (mm), in control and dorzolamide/timolol-treated eyes, and in control and tafluprost-treated eyes, throughout both of the experiment periods.

\begin{tabular}{|c|c|c|c|c|c|c|}
\hline Variables & Baseline & Day 1 & Day 2 & Day 3 & Day 4 & Post-treatment \\
\hline \multicolumn{7}{|c|}{ 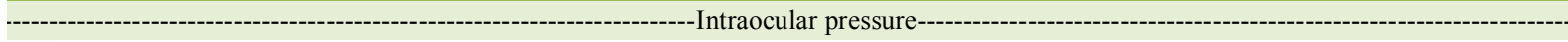 } \\
\hline Control & $16.41 \pm 0.20$ & $16.58 \pm 0.23$ & $15.92 \pm 0.33$ & $16.42 \pm 0.30$ & $16.14 \pm 0.27$ & $15.70 \pm 0.24$ \\
\hline Dorzolamide/timolol & $16.60 \pm 0.25$ & $15.86 \pm 0.33 \mathrm{a}$ & $14.72 \pm 0.28 \mathrm{Aa}$ & $13.66 \pm 0.26 \mathrm{Aa}^{*}$ & $13.50 \pm 0.26 \mathrm{Aa}^{*}$ & $14.36 \pm 0.27 \mathrm{Aa}$ \\
\hline Control & $16.95 \pm 0.26$ & $15.78 \pm 0.35$ & $16.38 \pm 0.26$ & $16.74 \pm 0.27$ & $16.22 \pm 0.28$ & $16.26 \pm 0.30$ \\
\hline Tafluprost & $16.96 \pm 0.20$ & $15.46 \pm 0.34 \mathrm{~A}$ & $14.78 \pm 0.39 \mathrm{Aa}$ & $14.82 \pm 0.29 \mathrm{Aa}$ & $14.78 \pm 0.29 \mathrm{Aa}$ & $15.30 \pm 0.35 \mathrm{Aa}$ \\
\hline \multicolumn{7}{|c|}{ - } \\
\hline Control & $4.76 \pm 0.09$ & $5.11 \pm 0.08$ & $5.12 \pm 0.09$ & $5.05 \pm 0.10$ & $5.17 \pm 0.11$ & $5.39 \pm 0.09$ \\
\hline Dorzolamide/timolol & $4.94 \pm 0.09$ & $4.86 \pm 0.09 \mathrm{a}$ & $4.79 \pm 0.07 \mathrm{a}$ & $4.56 \pm 0.08 \mathrm{Aa}$ & $4.87 \pm 0.08 \mathrm{a}$ & $5.10 \pm 0.08$ \\
\hline Control & $5.36 \pm 0.10$ & $6.06 \pm 0.15$ & $6.00 \pm 0.11$ & $5.53 \pm 0.14$ & $5.52 \pm 0.16$ & $5.07 \pm 0.10$ \\
\hline Tafluprost & $5.07 \pm 0.10$ & $2.75 \pm 0.16 \mathrm{Aa}^{*}$ & $2.51 \pm 0.14 \mathrm{Aa}^{*}$ & $2.64 \pm 0.17 \mathrm{Aa}^{*}$ & $2.37 \pm 0.17 \mathrm{Aa}^{*}$ & $5.01 \pm 0.18$ \\
\hline
\end{tabular}

Uppercase letters indicate significant differences with the baseline period listed in the same row $(\mathrm{P}<0.05)$. Lowercase letters indicate significant differences with respective control eyes listed in the top row $(\mathrm{P}<0.05)$. Asterisk indicate significant differences between dorzolamide/timolol and tafluprost treated-eyes. 


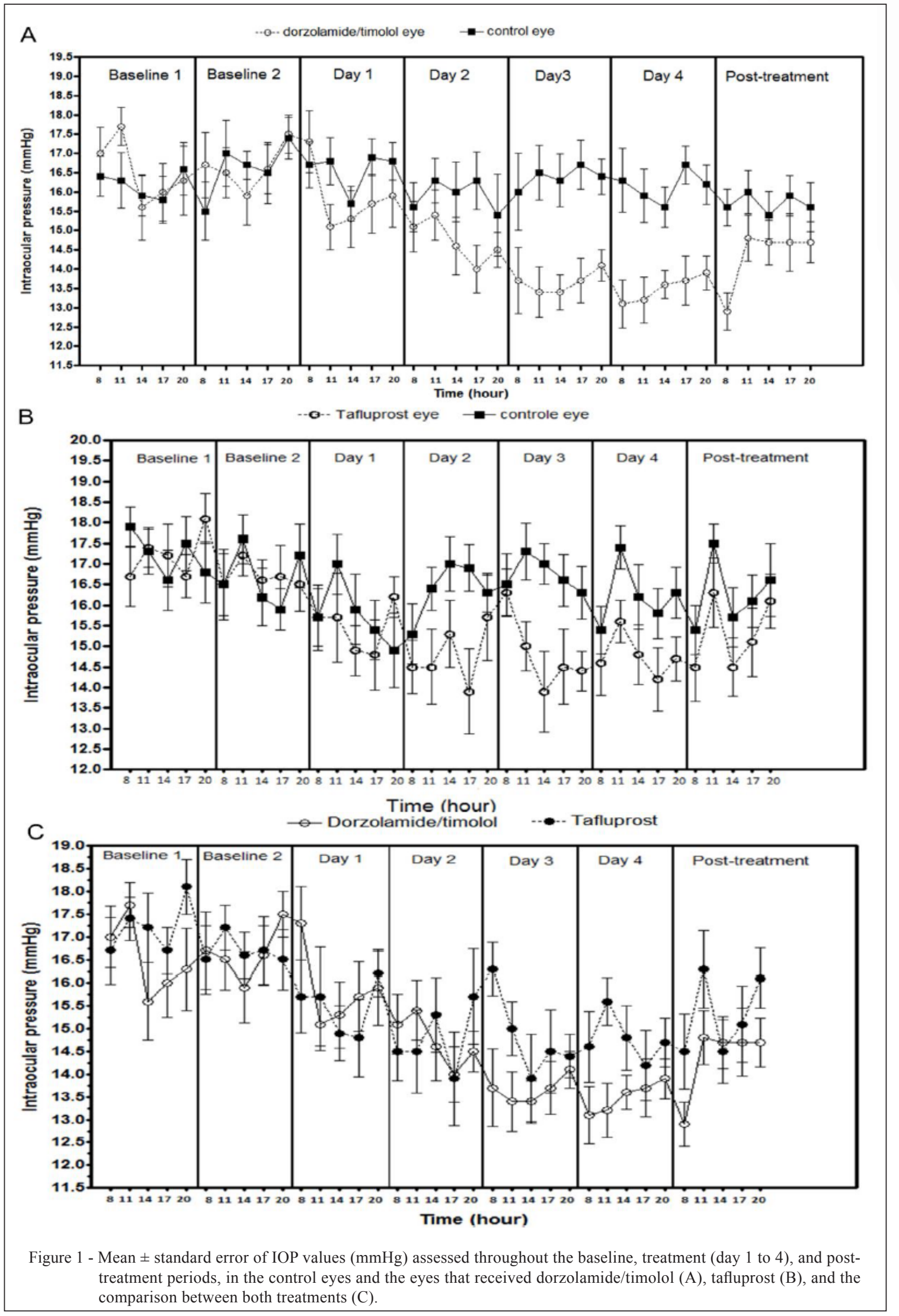

Ciência Rural, v.47, n.9, 2017. 
to have little or no effect on IOP in clinically normal dogs (SMITH et al., 2010). Previous reports have demonstrated that tafluprost was able to significantly decrease IOP in healthy dogs (TAKIYAMA et al., 2009; KWAK et al., 2017). However, in one of those researches, values of IOP were not described (TAKIYAMA et al., 2009). Despite KWAK et al. (2017) have acclimated dogs to tonometry, those authors did not compare the results of IOP assessed during the treatment period with the values obtained at the baseline period. In our research, comparisons between the average daily values of tafluprost-treated eyes with the average daily values of the baseline period, showed that IOP decreased significantly by $1.50,2.18,2.14$, and $2.18 \mathrm{mmHg}(\mathrm{P}<0.001)$ (Table 1 , Figure 1B). In one study, comparisons of the eyes that received tafluprost with the control eyes, showed that following four hours of a single instillation, IOP decreased significantly in the treated eyes for 24 hours (KWAK et al., 2017). In our research, significantly reductions in the IOP of tafluprost treated-eyes in comparison with the control eyes, only occurred from day two of the treatment phase. In the previous reports conducted in healthy dogs, the cumulative effect of repeated instillations of tafluprost were not evaluated (TAKIYAMA et al., 2009; KWAK et al., 2017). Differently from what it was observed in the eyes that received dorzolamide/timolol, in tafluprost-treated eyes, IOP did not change significantly during the treatment phase $(\mathrm{P}=0.25)$ (Table 1, Figure 1B). During the post-treatment phase, IOP in both dorzolamide/ timolol and tafluprost-treated eyes still maintained lower values in comparison to control eyes $(\mathrm{P}<0.001)$, and the baseline period $(\mathrm{P}<0.001)$ (Table 1$)$.

The absence of reports in the veterinary literature considering the comparison the of a carbonic anhydrase inhibitor, associated to timolol with a prostaglandin analogue motivated our research. In glaucomatous humans, direct comparisons between tafluprost and the fixed combination of dorzolamide/ timolol have to be interpreted with caution (SEO \& HA, 2015). Dorzolamide/timolol was able to sustain significantly lower IOPs than tafluprost over a period of 6 months; however, when the IOP-lowering effect of both agents were compared to baseline values, tafluprost was able to decrease IOP by $25.0 \%$, whereas the fixed combination of dorzolamide/ timolol reduced IOP by only $12.6 \%$ (SEO \& HA, 2015). Our results showed that, following three days of treatment, the fixed combination of dorzolamide/ timolol was more effective than the preservative-free tafluprost in reducing the IOP. In this regard, average daily IOP was 1.16 , and $1.28 \mathrm{mmHg}$ lower in the dorzolamide/timolol-treated eyes at day three and four, respectively, in comparison to tafluprost-treated eyes $(\mathrm{P}<0.05)$ (Table 1, Figure $1 \mathrm{C})$. During the posttreatment phase, IOP in dorzolamide/timolol-treated eyes maintained $0.94 \mathrm{mmHg}$ lower than tafluprosttreated eyes, but this reduction was not significant $(\mathrm{P}>0.05)$ (Table 1, Figure 1C).

Topical administration of timolol maleate is able to reduce PD in treated eyes of normotensive dogs and cats (PLUMMER et al., 2013). This effect may indicate $\beta$-adrenergic inhibition or $\alpha$-adrenergic activation of the iris sphincter muscle which may result in miosis (SMITH et al., 2010). It has been reported that the fixed combination of dorzolamide/timol decreased PD in glaucomatous dogs (PLUMMER et al., 2006). In normotensive dogs; however, this is the first paper that describes the effects of dorzolamide/timolol on PD. In our study, PD decreased significantly in dorzolamide/ timolol-treated eyes when comparisons were made with the baseline period, and with another days of treatment periods, only at day three of the treatment phase $(\mathrm{P}<0,05)$ (Table 1, Figure 2A). However, comparisons with the control eyes showed that PD of dorzolamide/treated eyes reduced significantly by $0.24(\mathrm{P}<0.01), 0.32(\mathrm{P}<0.01), 0.49(\mathrm{P}<0.001)$, and $0.40 \mathrm{~mm}(\mathrm{P}<0.001)$, from day one to day four of the treatment phase (Table 1, Figure 2A).

Like other PGAs, tafluprost exerts its miotic effect via PGF2 $\alpha$, which induces direct contraction of canine iris sphincter muscle (KWAK et al., 2017). In the present research, PD of tafluprosttreated eyes decreased significantly by $2.31,2.55$, $2.43,2.70 \mathrm{~mm}$, when compared to baseline period ( $\mathrm{P}<0.001)$; and by $3.30,3.48,2.89$, and $3.15 \mathrm{~mm}$ when compared to control eyes $(\mathrm{P}<0.001)$ (Table 1, Figure 2B). There are no reports in the current literature which considerate to compare the miosis-induction effect of an $\beta$-blocker with a PGA. Comparisons between treatments showed that tafluprost was more effective $(\mathrm{P}<0.001)$ in reducing $\mathrm{PD}$ throughout the treatment period (Table 1, Figure 2C). During the post-treatment phase, only dorzolamide/timololtreated eyes maintained lower PD values, when compared to control eyes $(\mathrm{P}<0.001)$, and the baseline period $(\mathrm{P}<0.05)$ (Table 1$)$.

The IOP-lowering effects exerted by both agents in our study, suggests that such agents could be able to reduce signs of pain that arouse from inadequate aqueous humor drainage in glaucomatous patients (PIZZIRANI, 2015). However, the present authors suggest that dorzolamide/timolol should be chosen to manage secondary canine glaucomas, 


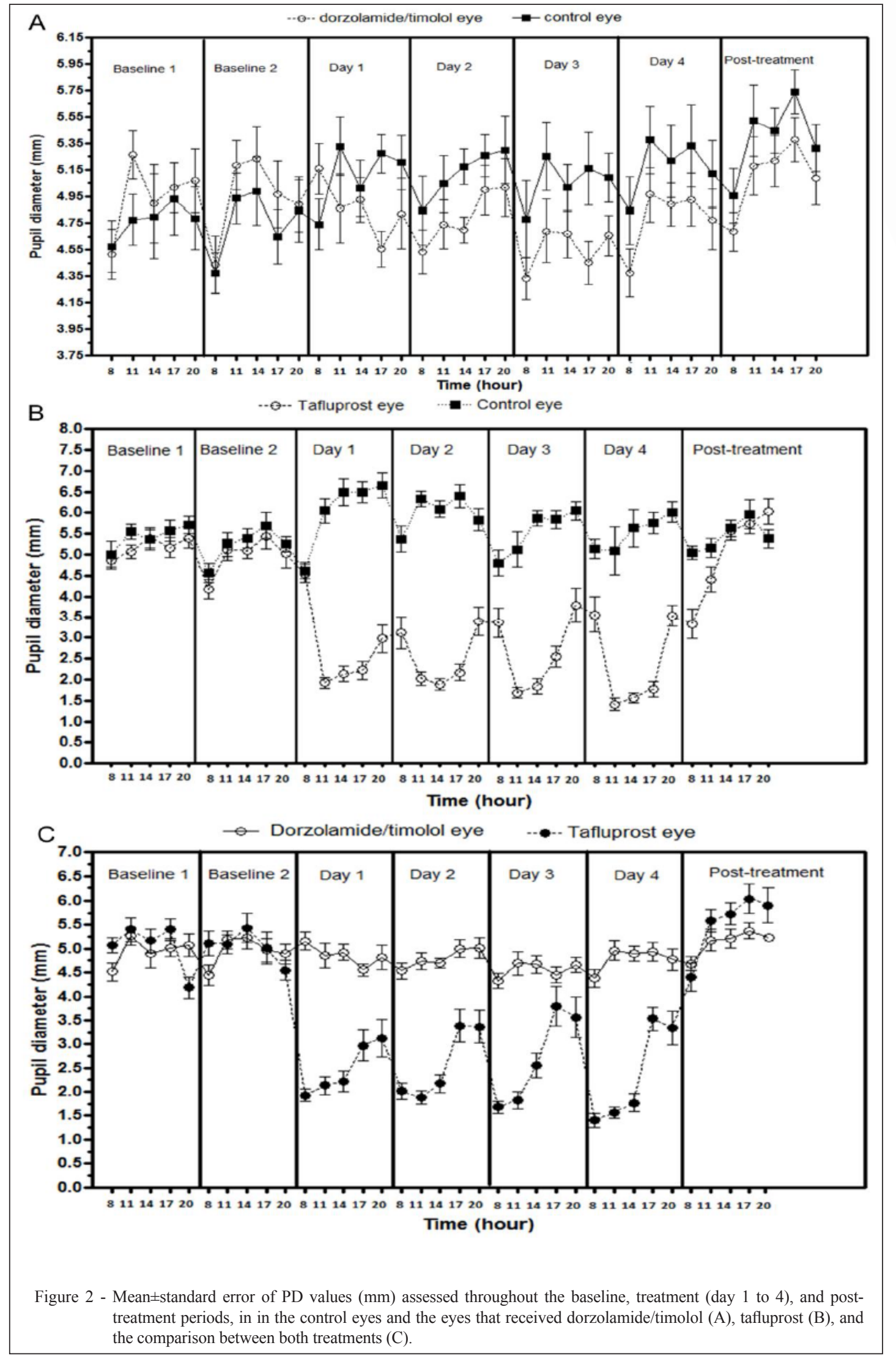

Ciência Rural, v.47, n.9, 2017. 
once the agent was more effective in lowering IOP and caused less miosis, a clinical sign undesirable in inflamed eyes (JOHNSTONE MCLEAN et al., 2008).

From our results, it can be concluded that the fixed combination of dorzolamide/timolol and the preservative-free tafluprost were able to decrease IOP and PD in healthy dogs. However, a cumulative effect of the fixed combination of dorzolamide/timolol was observed following three days of consecutive instillations. For this reason, dorzolamide/timolol was more effective in reducing IOP than tafluprost. Comparisons between treatments showed that tafluprost was more effective in reducing PD throughout the treatment period.

\section{BIOETHICS AND BIOSSECURITY COMMITTE APPROVAL}

This project was approved by the Research Ethics and Animal Experimentation of the Universidade Federal de Mato Grosso, with registration number 23108.092583/15-89.

\section{REFERENCES}

BORGES, A.G. et al. Efficacy of timolol maleate $0.5 \%$ dorzolamide hydrochloride $2 \%$, and the combination of both drugs on intraocular pressure. Arquivos Brasileiros de Medicina Veterináriae Zootecnia, v.59, n.3, p.660-664, 2007. Available from: <http:// www.scielo.br/pdf/abmvz/v59n3/a17v59n3.pdf>. Accessed: Oct 18, 2016. doi: 10.1590/S0102-09352007000300017.

CAWRSE, M.A. et al. Effects of topical application of a $2 \%$ solution of dorzolamide on intraocular pressure and aqueous humor flow rate in clinically normal dogs. American Journal of Veterinary Research, v.62, n.6, p.859-863, 2001. Available from: <http:// avmajournals.avma.org /doi/abs/10.2460/ajvr.2001.62.859>. Accessed: Oct. 18, 2016. doi: 10.2460/ajvr.2001.62.859

FOGAGNOLO, P. et al. A 1-year randomized study of the clinical and confocal effects of tafluprost and latanoprost in newly diagnosed glaucoma patients. Advances in Therapy, v.32, n.4, p.356-369, 2015. Available from: $<$ http://link.springer.com/article /10.1007\%2Fs 12325-015-0205-5>. Accessed: Oct. 18, 2016. doi: $10.1007 / \mathrm{s} 12325-015-0205-5$.

GELATT, K.N.; MACKAY, E.O. Changes in intraocular pressure associated with topical dorzolamide and oral methazolamide in glaucomatous dogs. Veterinary Ophthalmology, v.4, n.1, p.61-67, 2001. Available from: <http://onlinelibrary.wiley.com/ doi/10.1046/j.1463-5224.2001.00141.x/abstract>. Accessed: Oct. 18, 2016. doi: 10.1046/j.1463-5224.2001.00141.x.

GIANNICO, A.T. et al. Effects of prostaglandin analogs on blood flow velocity and resistance in the ophthalmic artery of rabbits. Arquivos Brasileiros de Oftalmologia, v.79, n.1, p.33-36, 2016. Available from: < http://www.scielo.br/pdf/abo/v79n1/0004-2749abo-79-01-0033.pdf> . Accessed: Oct. 18, 2016. doi: 10.5935/00042749.20160010
JOHNSTONE MCLEAN, N.S. et al. The effect of a single dose of topical $0.005 \%$ latanoprost and $2 \%$ dorzolamide $/ 0.5 \%$ timolol combination on the blood-aqueous barrier in dogs: a pilot study. Veterinary Ophthalmology, v.11, n.3, p.158-151, 2008. Available from: $<$ http://onlinelibrary.wiley.com/doi/10.1111/j.14635224.2008.00609.x/abstract>. Accessed: Oct. 18, 2016. doi: 10.1089/jop.2007.0065.

KWAK, J. et al. Effect of preservative-free tafluprost on intraocular pressure, pupil diameter, and anterior segment structures in normal canine eyes. Veterinary Ophthalmology, v.20, n.1, p.34-39, 2017. Available from: <http://onlinelibrary.wiley.com/doi/10.1111/ vop.12341/abstract>. Accessed: Jan. 07, 2017. doi: 10.1111/vop.12341.

OTA, T. et al. Prostaglandin analogues and mouse intraocular pressure: effects of tafluprost, latanoprost, travoprost, and unoprostone, considering 24-hour variation. Investigative Ophthalmology and Visual Science, v.46, n.6, p.2006-2011, 2005. Available from: <http://iovs.arvojournals.org/article. aspx? articleid $=2163929>$. Accessed: Oct. 18, 2016. doi: 10.1167/ iovs.04-1517.

PIZZIRANI, S. Definition, classification, and pathophysiology of canine glaucoma. Veterinary Clinics of North America: Small Animal Practice, v.45, n.6, p.1127-1157, 2015. Available from: $<$ http://www.sciencedirect.com/science/article $>$. Accessed: Jan. 07, 2017. doi: 10.1016/j.cvsm.2015.06.002.

PLUMMER, C.E. et al. Comparison of the effects of topical administration of a fixed combination of dorzolamide-timolol to monotherapy with timolol or dorzolamide on IOP, pupil size, and heart rate in glaucomatous dogs. Veterinary Ophthalmology, v.9, n.4, p.245-249, 2006. Available from: <http://onlinelibrary.wiley. com/doi/10.1111/j.1463-5224.2006.00469.x/abstract>. Accessed: Oct. 18, 2016. doi: 10.1111/j.1463-5224.2006.00469.x.

PLUMMER, C.E. et al. The canine glaucomas. In: GELATT, K.N. et al. Veterinary ophthalmology. 3.ed. Philadelphia: Lippincott Williams and Wilkins, 2013. Chap.19, p.1050-1145.

SEO, D.R.; HA S.J. Comparison of ocular pulse amplitude lowering effects of preservative-free tafluprost and preservativefree dorzolamide-timolol fixed combination eyedrops. BioMed Research International, 2015. Available from: <https://www. ncbi.nlm.nih.gov/pmc/articles/PMC4628750/>. Accessed: Jan. 07, 2017. doi: $10.1155 / 2015 / 435874$.

SMITH, L.N. et al. Effects of topical administration of latanoprost, timolol, or a combination of latanoprost and timolol on intraocular pressure, pupil size, and heart rate in clinically normal dogs. American Journal of Veterinary Research, v.71, n.9, p.10551061, 2010. Available from: <http://avmajournals.avma.org/ doi/abs/10.2460/ajvr.71.9.1055>. Accessed: Oct. 18, 2016. doi: 10.2460/ajvr.71.9.1055.

TAKIYAMA, N. et al. Effects of tafluprost $0.0015 \%$ compared with latanoprost $0.005 \%$ on the IOP and pupil size of normotensive dogs. In: ANNUAL MEETING OF THE AMERICAN COLLEGE OF VETERINARY OPHTHALMOLOGISTS, 40., 2009, Chicago, IL. Veterinary Ophthalmology, v.12, n.6, p.390-409, 2009. Available from: <http://onlinelibrary.wiley.com/doi/10.1111/ j.1463-5224.2012.01047.x/abstract>. Accessed: Oct. 18, 2016. doi: 10.1111/j.1463-5224.2009.00737.x 